\title{
THE USE OF FILMS IN TEACHING ENGLISH AS A SECOND LANGUAGE ${ }^{1}$
}

\author{
H. Joan Morley and Mary S. Lawrence ${ }^{2}$ \\ University of Michigan
}

\begin{abstract}
[These are the first two parts of a three-part report on the development of a program at the English Language Institute which uses documentary films for the improvement of aural comprehension, speaking, writing, and reading in English as a second language. Part $I$ is a general description of the program; Part II is a discussion of the writing aspects of the program; Part III, to appear in the next issue of Language Learning, will discuss the treatment of aural comprehension in the program. The program itself will be published under the title Films for Advanced Practice in Aural Comprehension, Vocabulary Building, and Composition, by H. Joan Morley and Mary S. Lawrence (Ann Arbor: University of Michigan Press, forthcoming).]
\end{abstract}

\author{
PART I: \\ OVERVIEW AND RATIONALE \\ H. Joan Morley
}

A survey of resources for teaching English as a second language (TESL) reveals that materials for the teaching of aural comprehension (i.e., listening with understanding) often suggest the use of commercial films for advanced practice. Two years' experimental work with documentary films in advanced English classes has demonstrated the value of such films not only for aural comprehension but much more. With the introduction of a structured

${ }^{1}$ An earlier version of this paper was presented at the ATESL section meeting of the Michigan NAFSA Conference, April 2-3, 1971 in Saginaw, Michigan.

2The authors wish to thank the University of Michigan Audio-Visual Education Center, its director Dr. Ford L. Lemler, and his assistants Miss Karen E. Sayer and Miss G. Maxine Baker, for especially helpful and courteous service and advice. Also grateful acknowledgement is given to the staff and administration of the English Language Institute for their indispensable roles in the development of the project reported here. 
sequence of supplementary guides and exercises, a series of carefully chosen films can serve as the core for a total skill-building curriculum of advanced aural comprehension, speaking, writing, and reading.

Films, a vital communication medium of the twentieth century which has been virtually untouched by TESL as a content tool, can be an almost limitless source of material for in-class English language practice. With careful choice and purposeful planning films can be utilized to their full potential and become a valuable teaching tool in the field of TESL.

This careful choice and purposeful planning are key factors in the development of a formal film program for skill-building. However, a third factor which must underlie both of these factors is philosophical-theoretical direction. In meeting these three demandsdirection, choice, and planning-five guidelines have been developed. These five considerations-a blueprint for developing a formal film program-will be discussed in this paper (sample exercises will be found in the Appendix and the other two parts of this article): (1) Defining the "roles" which films can play; (2) Establishing general purposes and specific language goals; (3) Establishing criteria for choosing and sequencing films; (4) Writing a structured set of supplementary guides and exercises for each film; (5) Involving the student in the learning process.

\section{"Roles"' Films Can Play}

What makes this program different from any other program which shows films? . The key here is the philosophy that films can be adapted to play the following three roles:

First, a film as used here is not an end in itself but a beginning. It is the stimulus which sets in motion a communication process which eventually involves all four skill modalities. Dynamic films dealing with controversial, international, personalsocial issues of our century can act as catalysts. With guidance they can provoke highly motivated spoken and written exchanges of ideas and opinions.

Second, the film is here conceived of as an active experience and not as a passive time-filler. Any really well-done film is an "experience" for its viewers-not just a pleasant sound and light diversion. Kuhns expresses this role as follows:

The experience of the film belongs to the viewer, and to no one else. A film which does not become for its viewer a moving, deeply felt experience, has no chance of challenging the imagination, drawing vital discussion, or stimulating sharp subjective 
meanings. Films are needed then to create the experience which is worth exploring. 3

It should be underscored in regard to foreign students that, though the film provides a more-or-less common experience, in fact, each person who views it also has a unique individual experience because of his particular cultural-social background. Follow-up language exercises (discussing and writing) must capitalize on the individualism of the student.

Third, the film "role" in a formal program of this kind is an integral content part of the in-class English instructional program. It is not an extra-curricular activity. This is somewhat different from the other profitable uses of films reported in the literature: language teaching (grammar, vocabulary, etc.); laboratory practice; cultural exchanges; orientation; entertainment.

\section{Purposes and Goals}

There are two underlying purposes of the film program. One is a linguistic purpose and one is an informational purpose. In simple words students not only learn English but they learn "something."

The informational purpose of the film program is specifically geared to the advanced student who is usually seeking competency in English for serious academic, business, or professional reasons. It is the intent of the film program to broaden the student's horizons with a short survey course in contemporary affairs. Through films (which are carefully chosen to reach this objective) and the supplementary work stemming from them, the student is encouraged to look at different aspects of problems and solutions, issues and answers. Specifically he is asked to form and to express his own opinions and to substantiate them in both written and spoken language.

The linguistic purpose is to provide advanced students with opportunities for live practice in listening, speaking, reading, and writing. In addition, particular attention is given to vocabulary building (both active and passive). Grammar and pronunciation problems are dealt with as they arise (but without disruption to the communicative nature of the expression).

(1) In sequence, the first skill is listening. Goals are concentration, directed listening, note-taking, and answering aural comprehension questions. As sample exercises will show, this includes advanced preparation with a study guide and oral vocabulary prac-

${ }^{3}$ Kuhns, William. 1968. Thernes: Shơrt Films for Discussion. Dayton, Ohio: Geo. H. Pflaum, Inc., p. 8 . 
tice. It also includes several showings of every film, each with a different but specific listening focus which is guided by question sheets. Students are often allowed to re-read; why not encourage them to "re-listen"?

(2) The second skill, in sequence is speaking. Goals here include participation in class discussion and giving short speeches. Expressions of personal viewpoints are encouraged as well as summary discussions of the information presented in the film. Again, sample exercises will show the kinds of questions provided to guide discussion. It is our strong conviction that in both of the areas of language where the student is the communicator (i.e., speaking and writing) one of the outstanding kinds of experience he ought to haveparticularly if he will be functioning in an English-speaking environment-is experience in how to discuss intelligently, how to agree, and how to disagree in linguistically sophisticated sociallyaccepted ways.

(3) The third skill is writing. The objective is to capitalize on the organizational and informational nature of each film. A set of writing assignments must be devised in which the content of the film is used not for classic regurgitation but as a springboard for the student's own ideas and opinions as triggered by the film and the ensuing discussions.

Through specific writing assignments the student is guided to combine content from the film, organization and logic from the film, and his own associations and inferences. He is urged to try new vocabulary and new methods of organization. The writing assignments range from simple to complex.

(4) The goal of the fourth skill, reading, is to provide several short current magazine or newspaper articles which duplicate and/ or supplement the information in the film. Vocabulary can be reinforced and extended, and methods of organization can be contrasted. Notice the attempt is not to teach reading but to give practice.

\section{Criteria}

Six criteria are followed in selecting films: relevance, sequence continuity, quality, intelligibility, organization, and vocabulary.

Relevance. The content of the film must be up-to-date. The subject matter must be current but "current" doesn't mean that the film must have been made today. To be timely, the critical point is that the content be enduring in its impact on society over the next 20 or 30 years. Additionally, although the films may be made in the United States, the scope of the subject should have 
international ramifications. Controversial issues are particularly stimulating in their linguistic productivity. Caution should be taken to assure students that they may take any side of an issue. No suggestion of brain-washing or propagandizing in favor of either the film's point of view or the individual teacher's personal opinion should be either stated or implied!

Sequence Continuity. To be most effective, a series of films should have a thread of continuity. The series we use includes the following films involving social, economic, and ecological areas of concern. 4

Food for Life. 22 minutes - color - National Dairy Council (Wexler) (representative problems of nutrition in the world today)

Meanings are in People. 24 minutes - color - Bureau of National Affairs (problems of communication)

Getting the News. 16 minutes - black and white - Encyclopedia Britannica Educational Films (importance of mass communication media)

Problems of Conservation: Air. 15 minutes - color - Encyclopedia Britannica (man and environmental destruction)

Conquering the Sea. 25 minutes - color - CBS News (McGrawHill) (exploiting the resources of the sea)

Trip from Chicago. 25 minutes - color - CBS News (McGrawHill) (mass transit problems and high speed transportation vehicles of the future)

Standing Room Only. 25 minutes - color-CBS News (McGrawHill) (Population explosion and birth control)

Wealth of the Wasteland. 27 minutes - color US Department of the Interior (recycling and reclaiming waste materials)

Dr. Leakey and The Dawn of Man (1). 25 minutes - color National Geographic Society (Encyclopedia Britannica Educational Films) (discovering clues to man's evolution)

Humanities: What They Are and What They Do. 28 minutes color - Encyclopedia Britannica Educational Films (man does not live by science alone; humanities and science, complementary not competitive)

Quality. The general quality of film production must be good. No one can become involved in a film when it is obvious that it is badly done from a technical point of view. It should be stressed that the physical considerations-sufficient darkness, comfortable seating, etc.-are essential for complete success of such a program.

${ }^{4}$ All films are available from the producer and/or distributor. Most are also available at a nominal rental fee from college and university audio-visual centers and state department of public instruction supply centers. 
Intelligibility. The sound track must be clear. Voices must be intelligible. Throughout the series variation in voices, dialects, and styles of speech must be achieved.

Organization. Different methods of organization should be illustrated by the films-including superordination and subordination, varieties of categorization and classification, contrast, comparison, cause and effect, example, illustration, analogy, etc. In the sequence the films should move from simple to complex organization.

Vocabulary. The amount and level of new vocabulary must be manageable.

\section{Supplementary Material}

Five steps are followed in the presentation of each film. Supplementary material must be written to accompany each. The steps are outlined below. Samples of exercises for steps 1 and 2 will be found in the Appendix at the end of this article. Details for steps 3 and 4 can be found in Part II of this article. Note that each step provides many exercises; it is probable that all exercises for a given film would not be used. Appropriate exercises can be chosen to fit the level and interests of a specific class.

\section{STEP 1: ADVANCED PREPARATION FOR AURAL COMPRE- HENSION}

1.1 Study Guide of Contents of the Film. (used before first showing)

1.2 Vocabulary for Oral Practice and Discussion (used before first showing)

STEP 2: AURAL COMPREHENSION AND CLASS DISCUSSION

2.1 General Discussion Questions (used after first showing)

PURPOSE

SUBJECT MATTER

Discussion of MOST IMPORTANT MESSAGE

Discussion of TITLE and RETITLING

2.2 Film Continuity Guide and Note Sheet (used during second showing of the film)

2.3 Specific Discussion Questions (used after second showing of the film)

2.4 Opinion Speech-Topic Questions (used after third showing of the film)

2.5 Test Questions (optional) 


\section{STEP 3: ADVANCED PREPARATION FOR WRITING}

3.1 Written Vocabulary Exercises (used after first showing of the film)

3.2 BEFORE YOU WRITE instructions (used after second showing of the film)

STEP 4: COMPOSITION EXERCISES

4.1 Specific Writing Assignments (used after second and/or third showings)

STEP 5: SUPPLEMENTARY READING

5.1 Selected Articles

Pedagogy

This formal film program is based on several assumptions. First, it is maintained that advanced students (and their teachers) should be involved cognitively in the learning process. The student should not have to guess at the reason for activities and exercises which he or she is asked to complete.

Second, this program is based on the notion that advanced students-and their teachers-should be involved cognitively in the content of the lessons. This is important because this approach takes the position that at the advanced level (if not at all levels) the English language student must be provided with classroom experience which successfully accomplishes carry-over (i.e., transfer) to the non-classroom environment in a natural and realistic manner. This is why one of the two parts of the dual purpose cited earlier is the informational purpose of presenting a short survey course in contemporary affairs. This enables a student to extend his knowledge in areas which are important in the world today and he does it through the medium of English.

Last, although no quantification is attempted, the following assumption, which has been discussed from time to time, is cited as an interesting conjecture:

It is possible that a student might become a better communicator in a non-native language in both receiving and sending if he is involved in a situation where he is working with new information and not information which is already known.

At any rate many advanced students seem to feel psychologically satisfied that the informational purpose of a film program such as this is a challenge to their intellects and equal in importance to the Iinguistic purpose of practicing English. 
Futurists predict that by the twenty-first century the written media may be reduced to artifacts of history while audio-visual media may become a major source of information exchange. Whether this prediction comes true or not remains to be seen. Certainly twentieth century ESL teachers (at least for the remaining years of the century) can avail themselves of an appealing and highly motivating vehicle for improving the four linguistic skillslistening, speaking, reading, and writing.

\section{PART II}

\section{USING FILMS TO TEACH WRITING SKILLS}

\section{Mary S. Lawrence}

Films in the composition class: Just another gimmick? A time-filler for the lazy teacher? Entertainment instead of learning? All are valid questions; all are possible but not unavoidable pitfalls when films are used to teach composition. For films to be beneficial to the student writer, they must help him learn how to write; all other criteria in the selection of films and in their method of classroom use are absolutely secondary. The first step, then, is for the teacher to decide precisely what particular writing skill is to be practiced. Then comes the selection of a film, or a segment of a film, and the development of writing exercises. Without the prior establishment of specific goals (not long-range generalities, such as "to help the students write more fluently"), the use of films in the writing class can well result in a hodgepodge of unrelated composition assignments. Part II of this article discusses a variety of ways in which films may be incorporated into writing programs whose aim is to develop general fluency in exposition. No attempt is made to cover the use of films in teaching what is usually designated as creative writing: short stories, poetry, plays, etc. The ideas and suggestions are applicable to both native speakers of English, and non-native speakers beyond the elementary level of proficiency.

A primary obstacle for the student film-viewer is listening comprehension; he must understand what the film says as well as what it shows. Any composition class in which films are used must take this into consideration. It is assumed here that the student is receiving instruction in how to listen as well as in how to write. The problem of listening comprehension can be eliminated by the use of non-dialog films, such as Two Men and a Wardrobe (Contemporary), Toys (Contemporary), Hand (Contemporary), An 
Occurrence at Owl Creek Bridge (Contemporary), Why Man Creates (Kaiser Foundation), which are suitable for composition teaching. Films are obviously one method of enlarging the student's passive vocabulary. Even at this recognition level, it may be difficult for the student to retain vocabulary, but the transfer of new vocabulary from non-productive to active skills is even more difficult. The student should be taught to recall vocabulary in associated groups; because the content of the film is presented concretely and visually this kind of recall is facilitated. The composition teacher can devise vocabulary exercises which demand the manipulation of the most useful vocabulary items, both single words and phrases. Such exercises facilitate recognition and recall; they will not, however, guarantee transfer to the student's core of active vocabulary unless he is given opportunity to choose to use them meaningfully in a sequence of spaced written assignments. The operative words here are utility and choice. Students do not need to be able to reproduce in their writing every single word of any given film. Some vocabulary items are more useful than others. Students must be made actively aware of this fact, lest they fall into the trap of memorizing vocabulary lists indiscriminately. They should choose for themselves appropriate vocabulary to remember. Vocabulary acquisition can also result from non-dialog films, where the teacher elicits questions about the words and phrases required to summarize or comment on the film. In the English Language Institute film program, the student is given a consecutive listing of the vocabulary items of each film to which he can refer. Before he writes about any film, however, he is given the following instructions:

Now you have seen the film, and done all the vocabulary and listening exercises for the film, try to RECALL the most important vocabulary in the film. To do this RECALL the content of the film. Next RECALL the organization of the film.

Now that you are thoroughly familiar with the film and its vocabulary, make a PERSONAL DECISION about what vocabulary will be the most useful for you. Do you need to remember all the technical terms, the colloquialisms, the figurative language? Decide for yourself.

When writing he is admonished:

Don't write what is easy for you. Choose to use new vocabulary. Be bold.

An essential skill for every student writer is the ability to summarize and paraphrase. Here, films can be a valuable adjunct 
to reading materials. They have a clear advantage over the usual conventional approach of asking students to summarize in their own words a written selection, in that they completely obviate the problems of student copying and plagiarism. The film, Standing Room Only, for example, has a sequence which shows an experiment with overpopulation in mice; in Dr. Leakey and the Dawn of Man there is a discussion of the evolution of the giraffe's long neck; Food For Life illustrates four kinds of malnutrition. All such films are suitable for teaching the skills of summary and paraphrase. More advanced students can be asked to summarize the content of filmed interviews and, more difficult, discussions in which speakers present conflicting opinions, as for example in Conquering the Sea and Standing Room Only. Similarly, the students can be asked to paraphrase certain concepts a film presents. They can explain in their own words, for instance, what is meant by "vast global slum," or "a surviving son as an economic necessity" (Standing Room Only), or "universality of the family" (Humanities, What They Are and What They $D o$ ). The entire film, Meanings Are In People, is devoted to the problems of misunderstanding in communication and therefore is a suitable addition to any classroom treatment of accuracy in paraphrase.

Films can be adapted to the teaching of traditional rhetorical methods of written organization. In this they serve a dual purpose. The student is taught to identify the method of organization in question as it is utilized in the film, and secondly, he can apply the rhetorical method in his own writing. Humanities, What They Are and What They Do, for instance, is an extended definition, and exemplifies many methods of handling definition which the student can practice in his writing. Food For Life graphically illustrates classification, cause and effect, while Getting the News combines chronological narration and classification. Composition teachers, therefore, should not see films as limited to the teaching of narration only.

Since narrative writing is probably the first basic skill taught in most expository writing classes, and is the easiest for the student to identify, it is a good place to introduce films for writing practice. Short non-dialog films such as Hand can produce good written assignments of chronological order. Some teachers may wish to show only part of a non-dialog narrative film like Two Men and a Wardrobe allowing the student to write the ending.

From narration, the student can proceed to writing classification, comparison, contrast, cause and effect, and definition based on films. The following are sample composition topics drawn from films: 
CLASSIFICATION.

Using the film as a source of data write a composition of classification about travel methods of the future. Start your composition with a generalization of classification. You need not use all the data from the film (Trip From Chicago).

GENERALIZATION AND SUBSTANTIATION.

The lecturer speaks of the combination of utility and beauty. Choose an example different from the one in the film to illustrate this combination. Write a brief paragraph on the working together of science and the humanities using your illustration. (Humanities...)

DEFINITION.

Write an extended definition of each of the following: news media, and public health service. In an extended definition the writer must include a full explanation of the term he is discussing. Include the major classification of the term. Use examples and concrete illustrations. (Getting the News)

\section{COMPARISON AND CONTRAST.}

Compare and contrast the waste disposal problems of an agricultural society and an industrial society. (Wealth of the Wasteland)

All of these assignments demand forms of written organization traditional in expository writing classes. In some the student is asked to write about information in precisely the way it was handled in the film: to write a classification composition of material that was presented through classification, for example. At a more advanced level he is asked to write about the content of the film utilizing a method of organization other than that in which it was presented.

Just as the student need not have in his active vocabulary all the words and phrases of the film, it is unnecessary for him to be able to reproduce in writing all the organizational devices of films. Indeed, given the fact that films, although often based on written scripts, are not a written means of communication, it would be impossible for him to do so. He should be able to identify and name some literary rhetorical devices even though he will not use them in his own writing. Figurative language, paradox, analogy, allegory, all of which cause non-native speakers of English particular difficulty, fall into this class. Students should be able to explain in writing the analogy of the girl and the amoeba in Food For Life, the paradoxes implied in Wealth of the Wasteland and in Problems of Conservation: Air. Similarly, they should be able to 
write a coherent interpretation of the allegory in Hand, Two Men and $a$ Wardrobe, and the ping-pong ball sequence in Why Man Creates. To repeat, the film should be chosen for the kind of writing skill to be practiced, whether it be the formulation of single sentences, exposition, or explication and interpretation.

At the English Language Institute films are used as an integral part of a composition program for upper-intermediate and advanced level foreign students. The total writing program, of which the film segment is only a part, is based on an approach to writing which is cognitive and semantic. Briefly, it is an enquiry method, focusing on question-framing, manipulation of data and extrapolation from data. The underlying cognitive theory is that of Jerome S. Bruner of Harvard University's Center for Cognitive Studies. Films are ideally suited to the teaching of writing using this approach.

Films are not shown until the student has had forty to fifty hours of writing instruction. By that time, he has some mastery of the basic writing skills he will need in order to complete the writing assignments based on the films. He can identify and has practiced the major methods of logical organization used in expository writing. For each organizational method he has been supplied with a variety of phrases and sentence patterns to use in writing. $\mathrm{He}$, therefore, has at his disposal a variety of ways to express classification, comparison, contrast, causality, and so on. The method used to teach written organization is by manipulation of data, and problem-solving; a method students can apply to films. Since the student is accustomed to imposing order on data, he need not be confined to summarizing or paraphrasing the content of the films. He is able to manipulate and re-order the information the film presents. Equally important, the writing program places much stress on synthesis of data. The student, therefore, can be asked to write on topics which demand a combination of information from the films and from his own personal store of data.

From the beginning of this writing program, the student is asked to formulate questions about the data he is given. The questions focus on logical relationships. This habit of logical questionframing is applied to both the content and organization of the films. The pre-writing instructions call for specific kinds of questionframing for each film. Moreover, while he is writing, the student is engaged in an internal dialog of question and answer.

Also from the outset of this writing program, emphasis is placed on the formulation of inferences. The student has had practice in distinguishing between explicit and implied information and in the written expression of inferences. The film composition 
assignments draw on this skill. In writing, the student not only is expected to remember information and ideas from the films but he must also make inferences and associations.

The film composition topics demand the combination of all the skills embodied in the total writing program: active recall, data manipulation, question-framing, extrapolation and synthesis. Such a combination demands a high degree of intellectualization on the part of the student. The stress on inference-making and synthesis ensures individualization in student responses.

The English Language Institute film series closely coordinates composition and listening comprehension. It is customary to link reading and writing. In fact, many composition courses, both for non-native and native speakers, are centered around reading selections. Because the relationship between listening skills and writing is not so obvious, it has not received the attention which our experience with classroom use of films at the English Language Institute indicates it deserves. We have found in the development of student skills a mutual interdependence between listening ability and writing ability. Clearly, more work is necessary before a definitive statement can be formulated. For the classroom teacher of composition it has major implications. Simply put, it seems likely that students who are taught how to listen will more easily learn how to communicate their ideas in writing. 


\section{APPENDIX}

Following are abridged samples of materials from Steps 1 and 2 as described on page 122 in Part I. These samples are taken from H. Joan Morley and Mary S. Lawrence's Films for Advanced Practice in Aural Comprehension, Vocabulary Building, and Composition (forthcoming).

\section{STEP 1.1: PREPARATION FOR AURAL COMPREHENSION}

\section{VOCABULARY \\ FOR ORAL PRACTICE \\ AND DISCUSSION}

FOOD FOR LIFE

(Directions:

Before you see the film it is important to study key vocabulary words and phrases in order to help you understand the film.

1. Be sure you understand the MEANING of each word or phrase. This is your RESPONSIBILITY. You know many of the words already. For words you do not know be sure to LOOK THEM UP in your DICTIONARY. ASK your teacher about meanings you do not understand.

2. In order to understand the words and phrases you need to know how they SOUND. Practice orally. REPEAT the pronunciation of each word and phrase after your teacher. Pay particular attention to syllable accent, stress and intonation. This will help you understand the words and phrases when you hear them in the films.)

VOCABULARY (grouped in order of first presentation)

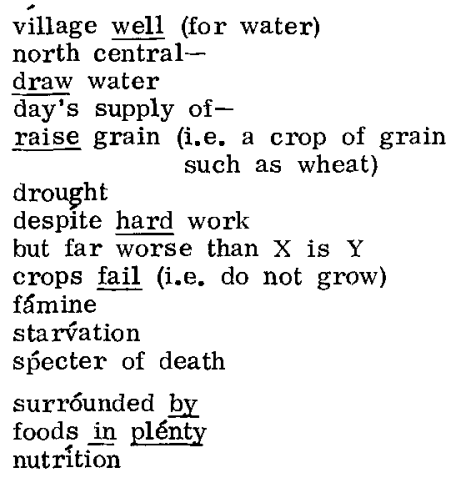

choice

malnutrition

in the midst of

édible root root (noun) grow wild (the opposite of cultivated) go húngry meat milk cheese enóugh to eat súffer from 
AURAL COMPREHENSION STUDY GUIDE

\section{FOOD FOR LIFE}

(Directions:

Your teacher will assign this study guide as homework. Please read it carefully. In class your teacher will read it aloud and answer any questions before the showing of the film. During the first showing of the film you do not need to take any notes. Listen for the GENERAL IDEAS OF the film. Follow these rules for good listening:

1. DO NOT TALK

2. DO NOT LET YOUR MIND "WANDER"

3. FORCE YOURSELF TO CONCENTRATE

4. AS YOU LISTEN REPEAT "KEY" FACTS AND FIGURES OVER TO YOUR SELF--IN ENGLISH!)

\section{OUTLINE OF CONTENTS}

I. Introduction to the film-a SUMMARY PREVIEW.

Four young people who have problems of poor nutrition are introduced. Brief explanations of their problems are given.

II. CAUSES of Malnutrition.

Four cases of malnutrition are presented and the causes explained.

1. Tara does not get enough food--

because of agricultural failure and consequent famine.

2. Karen has.....

3. Emilio has ......

4. Bob eats too much .....

III. RESULTS of malnutrition (i.e. MULTIPLE EFFECTS)

The results of malnutrition are PREDICTED for each of the four people,

1. Tara's general lack of food will .....

2. Karen's wrong choice of foods already shows .....

3. Emilio's lack of certain foods will probably result in-susceptibility to disease (particularly kwashiorkor) underdeveloped bodies shortened life

4. Bob's continued overeating may have these results .....

IV. POSSIBLE SOLUTIONS for each problem of malnutrition.

The solutions presented are PREDICTIONS which could become fact only if the CONDITIONS of who and how were met.

1. In Tara's situation agricultural productivity could .....

2. In Karen's situation her choice of foods could be improved if she learned and practiced balanced diet habits:

(Specifically-food from each of the 4 basic food groups-meats, milk, bread, and fresh fruit and vegetables.)

3. In Emilio's situation missing food nutrients could .....

4. In Bob's situation his overweight problem could .....

V. GENERALIZED statements are drawn from the 4 SPECIFIC problems ILLUSTRATED in the film.

The 4 problems presented illustrate the following GENERAL world food problems:

1. Like Tara more than half a billion people are subject to periodic famine.

2. Like Karen millions suffer from borderline deficiencies.

3. Like Emilio over a billion lack proteins they need.

4. Like Bob many millions are overweight.

VI. Conclusion to the film-SUMMARY of the sources of solutions. 
STEP 2.1: AURAL COMPREHENSION and CLASS DISCUSSION

\section{AURAL COMPREHENSION/ CLASS DISCUSSION \\ GENERAL QUESTIONS}

\section{FOOD FOR LIFE}

\section{(Directions:}

Please answer each question. Be prepared to present and defend your answers during class discussion.)

1. What were the PURPOSES of the film in your opinion? Choose one, two, three, or any number you believe appropriate. (Put them in rank order and number them accordingly.)
(1) to inform (general information)
(2) to instruct (specific method)
(3) to entertain
(4) to present a problem and purpose solutions
(5) to convince
(6) to arouse to action

2. What was the SUBJECT MATTER of the film? (4 or 5 words) The subject matter of the film was this:

3. What was the most important MESSAGE of Food for Life? (one sentence) The most important message of this film was this:

4. The TITLE of the film is Food for Life. Is that a good title? Why?

5. Think up a new title for the film and defend your choice. (i.e. tell why you chose it.) 
FILM CONTINUIT Y GUIDE AND NOTE SHEET

\section{FOOD FOR LIFE}

(Directions:

Your teacher will discuss these questions before the second showing. During the second showing listen for the answers to the questions and write them here.)

1. In the introduction of the film 4 young people from 3 countries of the world are introduced. Each represents a specific type of malnutrition problem. Many other countries could have been used for each of the examples, of course. What countries were the people from?

Tara was from

Karen was from

Emilio was from Bob was from

2. After each of the people has been introduced each of the 4 types of malnutrition problem is summarized briefly. Complete each statement.

Tara doesn't

Karen doesn't

Emilio doesn't

Bob

3. In the next part of the film each of the 4 problems is again discussed. The possible serious effects caused by each type of malnutrition are shown.

3a. Tara and the people of her village don't get enough to eat. What will happen if they don't get help?

3b. Fill in the blanks with the following words in correct order: starvation famine - death - drought causes ___ which causes which eventually causes

3c. Karen doesn't get the right things to eat. What are the effects on her right now?

3d. What will happen to Emilio and his family if they don't get the right chings to eat?

3e. What are the effects of kwashiorkon?

3f. Bob eats too much. What may happen to him if he doesn't stop eating too much and exercising too little?

$3 \mathrm{~g}$. What is the relationship between overweight and heart attack?

4. Next the film presents ways to help each person.

4a. What is needed to help Tara and her village? General: Specific:

4b. What should Karen do to help herself? General: Specific:

4c. What is needed to help Emilio and his family? General: Specific:

4d. What 2 things must Bob do to help himself?

5. Last, some statistics are given. (In general and not specific terms)

5a. How many people in the world are subject to periodic famine?

5b. How many people suffer from borderline deficiency?

$5 \mathrm{c}$. How many people lack the protein they need?

$5 \mathrm{~d}$. How many people are overweight? 
STEP 2.3: AURAL COMPREHENSION and CLASS DISCUSSION

\section{AURAL COMPREHENSION/DISCUSSION SPECIFIC QUESTIONS \\ FOOD FOR LIFE}

(Directions:

The words in capital letters are either words often used in TEST QUESTIONS or ORGANIZATIONAL words which you should understand. If you do not understand them, please ask your teacher to explain. Then answer the questions. Be prepared to defend them.)

1. List the 4 MAJOR CLASSIFICATIONS of food and give EXAMPLES of each.

2. A CONTRAST emphasizes differences.

What CONTRASTS were made between Karen and the amoeba.

3. A PARADOX is a state that seems contradictory.

Why does this seem to be a PARADOX but in reality is not.

"Malnutrition in the midst of plenty."

4. The following GENERAL solution was given: "India needs the mechanics and skills of modern agriculture." List four specific EXAMPLES of mechanies and skills needed.

5. Choose one of the RELATIONSHIPS below and give an EXAMPLE or TWO from the film.

STEP 2.4: AURAL COMPREHENSION and CLASS DISCUSSION

DISCUSSION/SPEECHES

FOOD FOR LIFE

(Directions:

Choose one of these questions and be prepared to present your answer in a 5-10 minute speech in class. Be prepared to defend your viewpoint.)

1. Do you agree/disagree partially/completely with any/all of the conclusions which were either stated or implied in the film? Please choose one idea from the film with which you strongly agree or disagree. State your opinion on it.

2. Do selections you have read agree or disagree in general? Comment. 
FOOD FOR LIFE

(Directions:

Please read each question very carefully. Remember to answer each only according to the information given in the film.)

1. Four examples of young people who are poorly nourished were given. Identify each (by name or country) and tell (in just a few words) why each was poorly nourished.

2. Name the four Food Groups discussed and give 2 examples of each.

3. What solution did the film give for each of the four problems of poorly nourished people?

4. Who was to provide the solution for each person?

5. Give a short answer to each of the following:

a. What causes kwashiorkor?

b. What are the effects of kwashiorkor?

c. What are two ways a fat person can lose weight (usually)?

d. Why does a fat person gain weight (usually)?

e. What are at least 2 things needed in order to improve food production in areas which have periodic drought and consequent famine?

6. Answer True or False to each of the following:

a. Statistics show there is no relationship between heart attack and overweight.

b. People who are overweight can expect to lose several years from their lives.

c. A good supply of food is a guarantee of good nutrition.

d. More than half of the people of the world don't have enough food of either the right quality or quantity.

7. What was the most important message of the film?

8. There were at least two examples of paradox in the film. Give one of them.

9. Define these phrases:
a. quality of food
b. quantity of food
c. susceptible to disease
d. malnourished 